\title{
Synthesis, Characterization and Antimicrobial Activity of p-Vanillin and Vanillin Schiff Bases
}

\author{
Abdullahi Owolabi Sobola ${ }^{*}$
}

${ }^{1}$ Department of Chemistry, Faculty of Science,

Lagos State University, Ojo

\section{${ }^{*}$ Correspondence}

Abdullahi Owolabi Sobola, Department of Chemistry,

Faculty of Science,

Lagos State University, Nigeria.

Email:abdullahi.sobola@lasu.edu.ng

\begin{abstract}
:
Introduction: The unending interest in the study of Schiff base ligands arise from the ease of their preparation and their versatility in several fields of Chemistry and Biochemistry. Some of the major biochemical processes such as trans-amination and glycosylation involve the formation of Schiff base intermediates. In addition, compounds containing the azomethine group have been found to often possess different biological activity such as anti-microbial, anti-viral and anti-inflammatory activity. In most cases, the extent of the potency depends on the nature of the constituent amino and or aldehyde moiety.

Aims: The aim of this study was to synthesize, characterize and evaluate the antimicrobial activity of Schiff base ligands derived from $p$-vanillin and vanillin.

Materials and Methods: The Schiff base ligands were prepared by condensing $p$-vanillin and vanillin with substituted aniline, aminonaphthalene and 3-aminopyridine respectively. The ligands have been characterized by elemental analysis, ${ }^{1} \mathrm{H}-$ \& ${ }^{13} \mathrm{C}-\mathrm{NMR}$, infrared, Raman and electronic spectral data. The antimicrobial study was carried out by screening the prepared ligands against Staphylococcus aureus subsp. aureus ATCC $₫ 6538^{\mathrm{TM}}$, Bacillus substillis subsp. spizizenii ATCC $\AA$ $6633^{\mathrm{TM} *}$, Escherichia coli ATCC $₫ 8739^{\mathrm{TM} *}$ and Candida albicans ATCC $\AA$ $2091^{\mathrm{TM} *}$ using agar diffusion technique.

Results: The azomethine, $\mathrm{HC}=\mathrm{N},{ }^{1} \mathrm{H}-\&{ }^{13} \mathrm{C}$-NMR signals were observed at $8.66-8.30 \mathrm{ppm}$ and $164.42-157.99 \mathrm{ppm}$ respectively. The infrared $v_{\mathrm{C}=\mathrm{N}}$ band appeared at $1622-1607 \mathrm{~cm}^{-1}$. The $p$-vanillin ligands exhibited higher activity than the vanillin based ligands. The p-hydroxyl and 3aminopyridine ligands possess significant antimicrobial activity especially, antifungal activity.

Conclusion: The study shows that the antimicrobial activity of the Schiff base ligands depends largely on the nature of the aldehyde moiety of the synthesized compounds.
\end{abstract}

Keywords: Salicylaldehyde, Schiff bases, anti-fungal agents, vanillin

(C) 2018 The Authors. Journal of Research and Reviews in Science - JRRS, A Publication of Lagos State University 


\section{INTRODUCTION}

The unending interest in the study of Schiff base ligands arise from the ease of their preparation and their versatility in several fields of Chemistry and Biochemistry. The first Schiff base compound was prepared by Hugo Schiff in 1861[1]. Schiff bases are prepared form one pot condensation reaction between primary amine and an aldehyde or ketone (ref.). Schiff bases play significant biological roles [2] in living systems, for example, in vision and in determining the flexibility of the wall of the veins, etc. Schiff base structures are involved in a number of biochemical processes such as transamination [3] and nonenzymatic glycosylation [4]. Furthermore, compounds containing the azomethine group have been found to often possess different biological activity such as antimicrobial [5-9], anti-viral [10] and anti-inflammatory activity [11-14]. In most cases, the extent of the potency depends on the nature of the substituents on the amino and or the aldehyde moiety. Study on Schiff base ligands is most often related to the salicylaldimine compounds due to their versatility in terms of synthesis and applications.

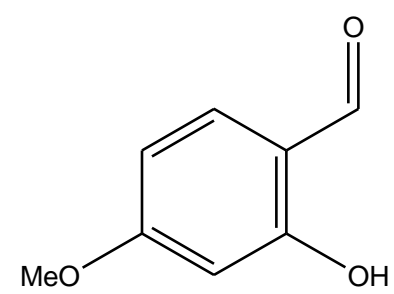

p-vanillin

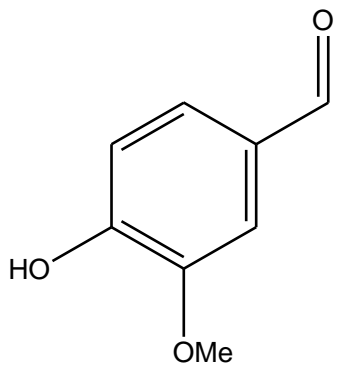

Vanillin
Fig. 1: Structures of $\mathrm{p}$-vanillin and Vanillin

Although, several studies have been reported on the synthesis and applications of Schiff bases compounds containing 2-hydroxylbenzaldehyde (salicylaldehyde) [15-19] and 2-hydroxyl-4-methoxylbenzaldehye (ovanillin) [20-23], similar attention has not been given to their closest analogues ( $p$-vanillin and vanillin) [24] . Para-vanillin is 2-hydroxy -4-methoxylbenzaldehyde while vanillin is 4-hydroxyl-3-methoxylbenzaldehyde as shown in figure 1 . The aim of this study, therefore, was to synthesize, characterize and evaluate the antimicrobial activity of Schiff base ligands derived from $p$-vanillin and vanillin

\section{MATERIAL AND METHODS}

All the chemicals and reagents were of reagent grade and used without further purification. The proton and carbon-13 NMR spectra were obtained from Bruker Avance NMR equipment operating at $400 \mathrm{MHz}$. The samples were dissolved in deuterated chloroform, $d_{1}$, with TMS as internal standard. The FT-IR absorption spectra were recorded on PerkinElmer Spectrum 100 FT-IR equipped with universal attenuated total reflectance (ATR) accessory, while Raman spectra were recorded on a Bruker Vertex 70 RAM 11 spectrophotometer using a $1064 \mathrm{~nm}$ ND-YAG laser. The electronic spectra were obtained from the PerkinElmer Lambda 25 spectrophotometer. The elemental analysis, CHN, was done on Vario MICRO V1.6.2 elemental analysen systeme $\mathrm{GmbH}$, while the melting points (uncorrected) of the compounds were determined using the Galenkemp melting point apparatus. All the micro-organisms were obtained from Microbiologics, Cape Town.

\subsection{Synthesis of the Schiff base ligands}

The Schiff base ligands were prepared according to the general procedure as reported in the literature [25-28]. The ligands were prepared by condensing equimolar amounts of $p$-vanillin or vanillin with $p$-substituted aniline, 1-aminonaphthalene, 3-aminopyridine and 3aminomethylpyridine respectively. Synthesis of the $p$ substituted aniline ligands has earlier been reported [28].

\section{Ligand L1}

$10 \mathrm{mmol}(1.522 \mathrm{~g})$ of $p$-vanillin in hot $10 \mathrm{ml}$ ethanol was mixed with $10 \mathrm{mmol}(0.91 \mathrm{ml})$ of aniline in hot ethanol and refluxed in $100 \mathrm{ml}$ round bottom flask for $1 \mathrm{hr}$ to obtain yellow precipitate. The precipitate was filtered under suction, washed with ethanol and dried in a desiccator. The same procedure was repeated for all the syntheses to obtain ligands L1 - L9 by condensing $p$-vanillin with aniline, $p$-chloroaniline, $p$-bromoaniline, $p$-methylaniline, $p$-methoxylaniline, $p$-nitroaniline, $p$ hydroxylaniline, 1-aminonaphthalene and 3aminopyridine respectively.

In the same vein, condensation of vanillin with the various amine compounds yielded ligands L10 - L17 under the same condition. The analytical and some selected spectral data for the compounds are presented in tables $1-3$.

\section{RESULTS AND DISCUSSION}

\subsection{Analytical and Elemental analysis}

The Schiff base ligands were obtained in good yield with relatively high purity as indicated by the elemental analysis result in table 1 . The experimental values of the microanalysis results were in close agreement with the calculated values. All the $p$-vanillin derived compounds have bright yellow colour while the vanillin analogues are mostly cream in colour. The variation in colour may be due to the position of the methoxy and the hydroxyl groups on the aldehyde moiety of the ligands. 


\section{$3.2{ }^{1} \mathrm{H}-N M R$ and ${ }^{13} \mathrm{C}-N M R$ Study}

The selected ${ }^{1} \mathrm{H}$-NMR and ${ }^{13} \mathrm{C}$-NMR spectral data for the compounds are presented in table 2. The characteristic azomethine proton, $\underline{\mathrm{HC}}=\mathrm{N}$, for the Schiff base ligands were observed as a strong $1 \mathrm{H}$ singlet at $8.66-8.30 \mathrm{ppm}$. This was further confirmed by the appearance of a strong carbon signal at 164.42 $157.99 \mathrm{ppm}$ corresponding to the azomethine carbon, $\mathrm{C}=\mathrm{N}$, of the Schiff base ligands. The signal due to the methoxyl group on the vanillin and $p$-vanillin moiety of the ligands was observed as $3 \mathrm{H}$ singlet at $4.02-3.88$ $\mathrm{ppm}$. In addition, the methyl protons of the $p$-toluidine Schiff base ligands appeared as $3 \mathrm{H}$ singlet at $2.41 \mathrm{ppm}$ in the ${ }^{1} \mathrm{H}$-NMR spectra of the compounds. The methoxyl and the methyl carbon signals were observed at 56.58 $-55.86 \mathrm{ppm}$ and $21.45 \mathrm{ppm}$ respectively.

Table 1: Analytical data for the Schiff base ligands

\begin{tabular}{|c|c|c|c|c|}
\hline Ligands & $\begin{array}{l}\text { Molecular } \\
\text { Formula }\end{array}$ & $\% \mathrm{C}$ & $\% \mathrm{H}$ & $\% \mathbf{N}$ \\
\hline L1 & $\mathrm{C}_{14} \mathrm{H}_{13} \mathrm{NO}_{2}$ & $\begin{array}{l}73.17 \\
(73.98)\end{array}$ & $\begin{array}{l}5.66 \\
(5.77)\end{array}$ & $\begin{array}{l}6.01 \\
(6.16)\end{array}$ \\
\hline L2 & $\mathrm{C}_{14} \mathrm{H}_{12} \mathrm{NO}_{2} \mathrm{Cl}$ & $\begin{array}{l}63.12 \\
(64.27)\end{array}$ & $\begin{array}{l}4.58 \\
(4.62)\end{array}$ & $\begin{array}{l}5.24 \\
(5.35)\end{array}$ \\
\hline L3 & $\mathrm{C}_{14} \mathrm{H}_{12} \mathrm{NO}_{2} \mathrm{Br}$ & $\begin{array}{l}54.13 \\
(54.92)\end{array}$ & $\begin{array}{l}3.78 \\
(3.95)\end{array}$ & $\begin{array}{l}4.45 \\
(4.57)\end{array}$ \\
\hline L4 & $\mathrm{C}_{15} \mathrm{H}_{15} \mathrm{NO}_{2}$ & $\begin{array}{l}73.83 \\
(74.66)\end{array}$ & $\begin{array}{l}6.18 \\
(6.27)\end{array}$ & $\begin{array}{l}5.69 \\
(5.80)\end{array}$ \\
\hline L5 & $\mathrm{C}_{15} \mathrm{H}_{15} \mathrm{NO}_{3}$ & $\begin{array}{l}69.21 \\
(70.02)\end{array}$ & $\begin{array}{l}5.83 \\
(5.88)\end{array}$ & $\begin{array}{l}5.35 \\
(5.44)\end{array}$ \\
\hline L6 & $\mathrm{C}_{14} \mathrm{H}_{12} \mathrm{~N}_{2} \mathrm{O}_{4}$ & $\begin{array}{l}61.42 \\
(61.76)\end{array}$ & $\begin{array}{l}4.40 \\
(4.44)\end{array}$ & $\begin{array}{l}10.28 \\
(10.29)\end{array}$ \\
\hline L7 & $\mathrm{C}_{14} \mathrm{H}_{13} \mathrm{NO}_{2}$ & $\begin{array}{l}68.71 \\
(69.12)\end{array}$ & $\begin{array}{l}5.46 \\
(5.39)\end{array}$ & $\begin{array}{l}5.79 \\
(5.76)\end{array}$ \\
\hline L8 & $\mathrm{C}_{18} \mathrm{H}_{15} \mathrm{NO}_{2}$ & $\begin{array}{l}77.28 \\
(77.95)\end{array}$ & $\begin{array}{l}5.36 \\
(5.45)\end{array}$ & $\begin{array}{l}4.90 \\
(5.05)\end{array}$ \\
\hline L9 & $\mathrm{C}_{13} \mathrm{H}_{12} \mathrm{~N}_{2} \mathrm{O}_{2}$ & $\begin{array}{l}67.63 \\
(68.40)\end{array}$ & $\begin{array}{l}5.29 \\
(5.29)\end{array}$ & $\begin{array}{l}12.09 \\
(12.27)\end{array}$ \\
\hline L10 & $\mathrm{C}_{14} \mathrm{H}_{13} \mathrm{NO}_{2}$ & $\begin{array}{l}74.01 \\
(73.98)\end{array}$ & $\begin{array}{l}5.87 \\
(5.73)\end{array}$ & $\begin{array}{l}6.16 \\
(6.16)\end{array}$ \\
\hline L11 & $\mathrm{C}_{14} \mathrm{H}_{12} \mathrm{NO}_{2} \mathrm{Cl}$ & $\begin{array}{l}64.68 \\
(64.27)\end{array}$ & $\begin{array}{l}5.01 \\
(4.62)\end{array}$ & $\begin{array}{l}5.34 \\
(5.35)\end{array}$ \\
\hline L12 & $\mathrm{C}_{14} \mathrm{H}_{12} \mathrm{NO}_{2} \mathrm{Br}$ & $\begin{array}{l}54.94 \\
(54.92)\end{array}$ & $\begin{array}{l}3.93 \\
(3.95)\end{array}$ & $\begin{array}{l}4.52 \\
(4.57)\end{array}$ \\
\hline L13 & $\mathrm{C}_{15} \mathrm{H}_{15} \mathrm{NO}_{2}$ & $\begin{array}{l}74.64 \\
(74.66)\end{array}$ & $\begin{array}{l}6.24 \\
(6.27)\end{array}$ & $\begin{array}{l}5.56 \\
(5.80)\end{array}$ \\
\hline L14 & $\mathrm{C}_{15} \mathrm{H}_{15} \mathrm{NO}_{3}$ & $\begin{array}{l}70.76 \\
(70.02)\end{array}$ & $\begin{array}{l}6.41 \\
(5.88)\end{array}$ & $\begin{array}{l}5.47 \\
(5.44)\end{array}$ \\
\hline L15 & $\mathrm{C}_{14} \mathrm{H}_{13} \mathrm{NO}_{2}$ & $\begin{array}{l}68.38 \\
(69.12)\end{array}$ & $\begin{array}{l}5.72 \\
(5.39)\end{array}$ & $\begin{array}{l}5.57 \\
(5.76)\end{array}$ \\
\hline L16 & $\mathrm{C}_{18} \mathrm{H}_{15} \mathrm{NO}_{2}$ & $\begin{array}{l}77.95 \\
(77.95)\end{array}$ & $\begin{array}{l}5.54 \\
(5.45)\end{array}$ & $\begin{array}{l}5.04 \\
(5.05)\end{array}$ \\
\hline L17 & $\mathrm{C}_{13} \mathrm{H}_{12} \mathrm{~N}_{2} \mathrm{O}_{2}$ & $\begin{array}{l}68.35 \\
(68.40) \\
\end{array}$ & $\begin{array}{l}5.48 \\
(5.29) \\
\end{array}$ & $\begin{array}{l}12.03 \\
(12.27)\end{array}$ \\
\hline
\end{tabular}

signal at $13.97-12.27 \mathrm{ppm}$ due to a strong intramolecular hydrogen bonding [15] within the Schiff base ligands. However, the hydroxyl signal for the vanillin based ligands resonated at $7.02-6.06 \mathrm{ppm}$ except for the $p$-hydroxyl Schiff base ligand, which occurred at $9.53 \mathrm{ppm}$

\subsection{Infrared and Raman Study}

The infrared spectral data for the compounds are presented in table 3 . The stretching vibration band for the phenolic hydroxyl group was nearly non-evident in the spectra of the $p$-vanillin Schiff base ligands due to strong intra-molecular hydrogen bonding typical of the ortho-hydroxylbenzaldimines [17, 29]. The presence of the hydroxyl group was substantiated by the appearance of a prominent band at $1286-1271 \mathrm{~cm}^{-1}$ corresponding to $v_{\mathrm{C}-\mathrm{O}}$ stretch of the hydroxyl group [16, 29]. The free phenolic $\mathrm{OH}$ group of the vanillin ligands was, however, observed as a strong and broad band at $3453-3362 \mathrm{~cm}^{-1}$. In addition, the formation of the Schiff base ligands was inferred from the appearance of the $v_{\mathrm{C}=\mathrm{N}}$ band at about $1622 \mathrm{~cm}^{-1}$ and $1614-1607 \mathrm{~cm}^{-1}[15$, 16] for the vanillin and the $p$-vanillin ligands respectively. This was further confirmed with the Raman spectral data for the ligands.

Some selected Raman spectral data for the compounds are presented in table 3 . The data further substantiates the formation of the Schiff base ligands. The imine functional group, $\mathrm{C}=\mathrm{N}$, was observed as a strong peak at $1632-1611 \mathrm{~cm}^{-1}$ very close to the ring stretch peak [30]. The ring stretch, $C=C$, appeared as intense doublets at $1609-1567 \mathrm{~cm}^{-1}$ in the spectra of some of the compounds. The medium peaks at $3072 \mathrm{~cm}^{-1}$ and $1228-1118 \mathrm{~cm}^{-1}$ correspond to the aromatic $\mathrm{C}-\mathrm{H}$ stretch and deformations respectively [30]. 
Table 2: Selected ${ }^{1} \mathrm{H}-$ and ${ }^{13} \mathrm{C}-\mathrm{NMR}$ spectral data

Table 3: Selected Infrared, Raman and UV/Visible

\begin{tabular}{|c|c|c|c|c|c|c|c|c|c|c|c|}
\hline \multirow[t]{3}{*}{ Ligands } & \multicolumn{3}{|c|}{ 'H-NMR (ס) } & \multicolumn{2}{|c|}{${ }^{73}$ C-NMR (ס) } & \multicolumn{6}{|c|}{ Spectral data for the Schiff bases } \\
\hline & \multirow[t]{2}{*}{$\underline{\mathrm{H}} \mathbf{C}=\mathrm{N}$} & \multirow[t]{2}{*}{$\mathrm{O} \underline{\mathrm{H}}$} & \multirow[t]{2}{*}{$\mathrm{OC}_{3}$} & \multirow{2}{*}{$\mathrm{C}_{3}$} & \multirow[t]{2}{*}{$\begin{array}{l}\text { ppm } \\
\text { HCE}=N\end{array}$} & \multirow[t]{3}{*}{ Ligands } & \multicolumn{2}{|c|}{$\operatorname{IR}\left(\mathrm{cm}^{-1}\right)$} & \multicolumn{2}{|c|}{$\operatorname{Raman}\left(\mathrm{cm}^{-1}\right)$} & \multirow[t]{3}{*}{$\lambda_{\max }(\mathbf{n m})$} \\
\hline & & & & & & & $v_{\mathrm{C}=\mathrm{N}}$ & $v_{C-0}$ & $\boldsymbol{v}_{\mathrm{C}=\mathbf{N}}$ & $v_{\mathrm{C}=\mathrm{C}}$ & \\
\hline L1 & 8.57 & 13.84 & 3.88 & ------- & 161.90 & & & & & & \\
\hline $\mathrm{L} 2$ & 8.53 & 13.54 & 3.88 & ------- & 162.30 & \multirow[t]{2}{*}{ L1 } & \multirow[t]{2}{*}{1613} & \multirow[t]{2}{*}{1287} & \multirow[t]{2}{*}{1613} & \multirow{3}{*}{$\begin{array}{l}1592, \\
1575\end{array}$} & \multirow{5}{*}{$\begin{array}{l}224,236, \\
285,334, \\
412 \\
228,237 \\
291,339 \\
415\end{array}$} \\
\hline L3 & 8.53 & 13.52 & 3.88 & ------ & 162.33 & & & & & & \\
\hline L4 & 8.56 & 13.96 & 3.88 & 2.41 & 161.01 & \multirow{3}{*}{ L2 } & \multirow{3}{*}{1607} & \multirow{3}{*}{1286} & \multirow{3}{*}{1615} & & \\
\hline L5 & 8.54 & 13.97 & 3.87 & ----- & 160.03 & & & & & \multirow{2}{*}{$\begin{array}{l}1591 \\
1572\end{array}$} & \\
\hline L6 & 8.58 & 13.10 & 3.90 & ------- & 164.42 & & & & & & \\
\hline L7 & 8.43 & $\begin{array}{l}13.97, \\
9.63\end{array}$ & 3.80 & ------ & 160.48 & \multirow[t]{2}{*}{ L3 } & \multirow[t]{2}{*}{1607} & \multirow[t]{2}{*}{1288} & \multirow[t]{2}{*}{1614} & $\begin{array}{l}1584 \\
1570\end{array}$ & $\begin{array}{l}227,237 \\
292,340\end{array}$ \\
\hline L8 & 8.66 & 13.90 & 3.87 & ------- & 162.99 & & & & & & 415 \\
\hline L9 & 8.56 & 12.27 & 3.87 & ------- & 163.81 & L4 & 1613 & 1288 & 1628 & $\begin{array}{l}1605 \\
1573\end{array}$ & $\begin{array}{l}224,238, \\
283,\end{array}$ \\
\hline L10 & 8.38 & 6.15 & 4.00 & -------- & 160.43 & & & & & & 336,414 \\
\hline L11 & 8.35 & 6.10 & 4.02 & -------- & 160.68 & L5 & 1614 & 1286 & ------- & 1595, & 213, 236, \\
\hline L12 & 8.30 & 6.10 & 4.00 & -------- & 160.71 & & & & & & $\begin{array}{l}286,293, \\
343420\end{array}$ \\
\hline L13 & 8.40 & 6.10 & 3.88 & 2.41 & 159.87 & L6 & 1614 & 1286 & - & 1585 & $\begin{array}{l}343,420 \\
359\end{array}$ \\
\hline L14 & 8.40 & 6.10 & 3.86 , & -------- & 158.64 & & & & & 1558 & \\
\hline L15 & 8.43 & $\begin{array}{l}9.53 \\
9.53\end{array}$ & $\begin{array}{l}4.01 \\
3.84\end{array}$ & - & 157.99 & $\mathrm{~L} 7$ & 1607 & 1286 & 1632 & 1609 & $\begin{array}{l}244,283 \\
295,342, \\
342,419\end{array}$ \\
\hline L16 & 8.47 & 6.06 & 4.00 & ------- & 160.43 & L8 & 1607 & 1287 & 1613 & 1567 & 228,342 \\
\hline L17 & 8.38 & 7.02 & 4.00 & ------- & 162.16 & & & & & & 381 \\
\hline & & & & & & L9 & 1608 & 1285 & 1611 & 1565 & $\begin{array}{l}235,288 \\
331,415\end{array}$ \\
\hline & & & & & & L10 & 1622 & 1282 & 1623 & $\begin{array}{l}1586 \\
1515\end{array}$ & $\begin{array}{l}227,284, \\
326,441\end{array}$ \\
\hline & & 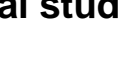 & & & & L11 & 1623 & 1276 & 1624 & 1601 & 231,285 \\
\hline electron & study of & Schif & sec & ounds & & & & & & 1584 & 330,442 \\
\hline $\begin{array}{l}\text { ied out in } \\
\text { the compo }\end{array}$ & $\begin{array}{l}\text { methano } \\
\text { unds are }\end{array}$ & $\begin{array}{l}\text { and the } \\
\text { resente }\end{array}$ & $\begin{array}{l}\text { elected } \\
\text { in table }\end{array}$ & $\begin{array}{l}\text { oectral } \\
\text {. The } ₫\end{array}$ & & L12 & 1622 & 1279 & 1622 & $\begin{array}{l}1599 \\
1579\end{array}$ & $\begin{array}{l}230,285 \\
331,444\end{array}$ \\
\hline $\begin{array}{l}e \text { ligands } \\
\text { ids at } 228\end{array}$ & $\begin{array}{l}\text { exhibite } \\
-213 \mathrm{nr}\end{array}$ & $\begin{array}{l}\text { two hi } \\
\text { and } 24\end{array}$ & $\begin{array}{r}\text { energ } \\
-231 n\end{array}$ & $\begin{array}{l}\text { absorp } \\
\text { due to }\end{array}$ & & L13 & 1623 & 1277 & 1624 & 1592 & $\begin{array}{l}227,283 \\
329,430\end{array}$ \\
\hline $\begin{array}{l}\pi^{*} \text { transiti } \\
\text { other ban }\end{array}$ & $\begin{array}{l}\text { on of the } \\
\text { ids were }\end{array}$ & $\begin{array}{l}\text { enzene } \\
\text { bserved }\end{array}$ & $\begin{array}{l}\text { ngs [16 } \\
\text { tt } 295-\end{array}$ & $\begin{array}{l}\text { In addit } \\
82 \mathrm{~nm}\end{array}$ & & L14 & 1623 & 1285 & 1623 & 1594 & $\begin{array}{l}227,284, \\
336,441\end{array}$ \\
\hline $\begin{array}{l}1-330 \mathrm{~nm} \\
\text { ansitions of }\end{array}$ & $\begin{array}{l}\text { corresp } \\
\text { the azor }\end{array}$ & $\begin{array}{l}\text { nding to } \\
\text { ethine } g\end{array}$ & $\begin{array}{l}\text { he } \Pi \rightarrow T \\
\text { up, } H C\end{array}$ & $\begin{array}{l}\text { and } n- \\
V \text { [31]. }\end{array}$ & & L15 & 1623 & 1275 & 1624 & 1588 & $\begin{array}{l}243,282 \\
337\end{array}$ \\
\hline $\begin{array}{l}\text { pearance } \\
\text { dicates the }\end{array}$ & $\begin{array}{l}\text { f a low } \\
\text { existence }\end{array}$ & $\begin{array}{l}\text { nergy } b \\
\text { f keto- } \epsilon\end{array}$ & $\mathrm{nd}$ at 4 & -412 & & L16 & 1622 & 1283 & 1621 & $\begin{array}{l}1596 \\
1572\end{array}$ & $\begin{array}{l}210,231 \\
320,337\end{array}$ \\
\hline hiff base I & lands [3 & & & & & L17 & 1620 & 1271 & 1622 & $\begin{array}{l}1598 \\
1579\end{array}$ & $\begin{array}{l}239,289, \\
328\end{array}$ \\
\hline
\end{tabular}

\subsection{Antimicrobial Study}

The Schiff base ligands were screened for their in vitro antimicrobial activity against three bacterial strains (Staphylococcus aureus subsp. aureus ATCC $\AA$ $6538^{\mathrm{TM} *}$, Bacillus subtilis subsp. spizizenii ATCC $\AA$ $6633^{\mathrm{TM} *}$ and Escherichia coli ATCC $® 8739^{\mathrm{TM} *}$ ) and one fungal strain (Candida albicans ATCC $\circledast 2091^{\mathrm{TM} *}$ ) using disc diffusion method [34].

The test organisms were cultured on nutrient agar medium. Each test organism was inoculated onto a nutrient agar plate and incubated at $37{ }^{\circ} \mathrm{C}$ for $24 \mathrm{hr}$ to obtain the primary culture. Several discrete colonies of the culture were dissolved in $10 \mathrm{~mL}$ saline water to obtain bacterial suspension corresponding to $106-108$ 
CFUs. The turbidity of the suspension was compared with $0.5 \mathrm{McF}$ arland standard. $0.1 \mathrm{~mL}$ of the bacterial suspension was inoculated onto Mueller Hinton plate and sterile discs containing the test compounds were firmly placed on the plate. The assay was incubated at $37^{\circ} \mathrm{C}$ for $16 \mathrm{hr}$ and the zone of inhibition was measured as millimetres diameter. The control solvent for the assay was dimethylformamide (DMF) while ampicillin was used as the standard antibacterial drug. The antifungal study was conducted in similar manner by replacing Mueller Hinton with potato disc assay and using ketoconazole as the standard antifungal agent. The test was repeated two more times for those compounds that showed activity of more than $6.5 \mathrm{~mm}$; and their activity was recorded as average zone of inhibition as presented in figures 2 and 3.

The $p$-vanillin ligands exhibited higher antimicrobial activity than the vanillin based ligands, probably due to the electronic effect of the $p$-methoxyl group on the $p$ vanillin ligands. Similar ligands with the o-methoxyl group (2-hydroxyl-3-methoxylbenzaldimines), however, exhibited higher activity, while the un-substituted salicylaldimine (2-hydroxylbenzaldimines) ligands were nearly non-active against the tested organisms [34]. Furthermore, the p-hydroxyl and the 3-aminopyridine ligands possess higher activity than the aniline derived Schiff base ligands. The compounds exhibited significant antifungal activity against Candida albicans and slight activity against $\mathrm{E}$. coli. The gram positive bacterial strains were more susceptible to the test compounds than Escherichia coli ATCC $® 8739^{\mathrm{TM}}$ *. The cell wall of Gram negative bacteria such as E. coli, is made up of thick peptidoglycan membrane and this reduces the permeation of the test compounds into the bacteria. Consequently, gram negative bacteria exhibit higher resistance to antimicrobial agents.

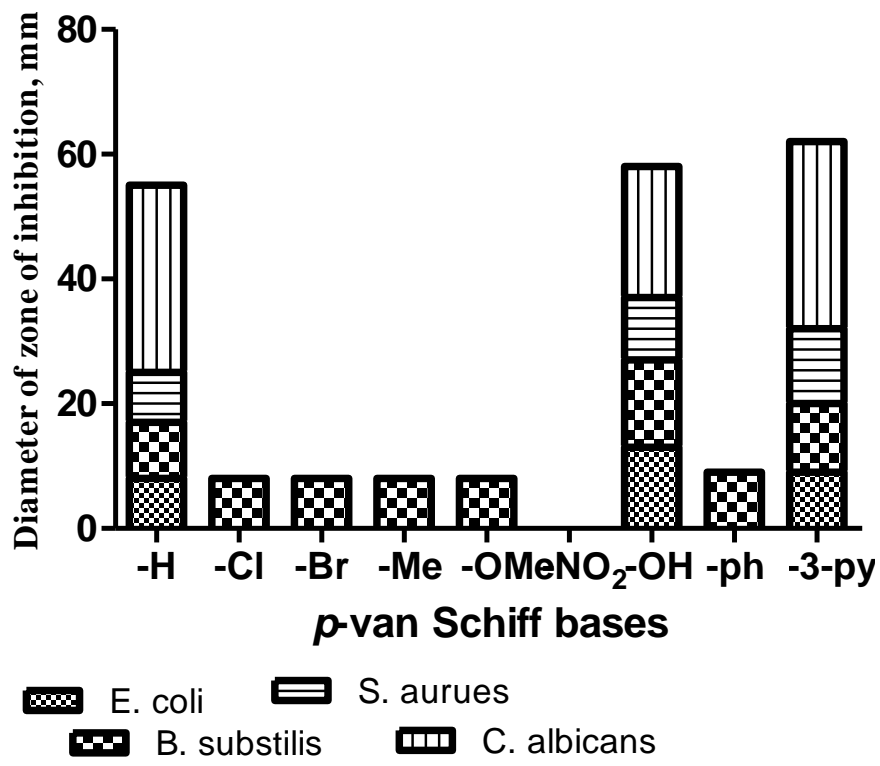

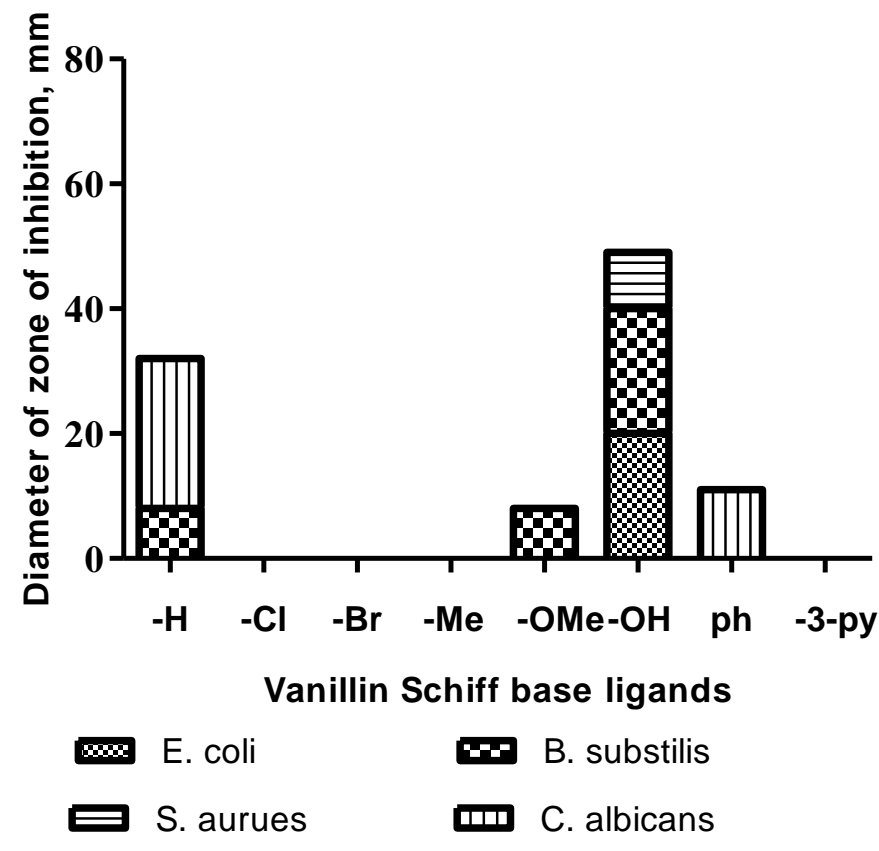

Fig. 3: Disc diffusion result for the vanillin ligands

\section{CONCLUSION}

The $p$-vanillin and vanillin Schiff base ligands were successfully prepared. The antimicrobial activity of the compounds depends on the nature of the aldehyde moiety of the Schiff base ligands. The p-hydroxyl and 3amainpoyridine ligands exhibited promising antifungal activity.

\section{ACKNOWLEDGEMENTS}

The authors are grateful to Prof. GM Watkins and Chemistry Department, Rhodes University, Grahamstown, for providing facilities for this research.

\section{COMPETING INTERESTS}

Authors have declared that no competing interests exist.

\section{REFERENCES}

1. Schiff $H$. Mitteilungen aus dem universitats laboratorium in Pisa: Eineneue reihe organischer basen. Justus Liebigs Ann Chem. 1864:131:118-19.

2. Voet D, Voet JG. Biochemistry. 2nd ed. New York: Wiley; 1995. 
3. Schmid GH, Organic Chemistry. New York, William C Brown Publishers; 1996.

4. McKee T, McKee J, Biochemistry. Dubuque. William C Brown Publishers; 1996

5. Ayhan KG, Altanlar N. Synthesis and antifungal properties of some benzimidazole derivatives. Turkish Journal of Chemistry. 2006: 30: 223-28.

6. Bagihalli GB, Avaji PG, Patil SA, Badami PS. Synthesis, spectral characterization, in vitro antibacterial, antifungal and cytotoxic activities of Co (II), Ni (II) and Cu (II) complexes with 1, 2, 4-triazole Schiff bases. European journal of medicinal chemistry, 2008: 43(12): 2639-49.

7. Wang H, Yuan H, Li S, Li Z, Jiang, M. Synthesis, antimicrobial activity of Schiff base compounds of cinnamaldehyde and amino acids. Bioorganic \& medicinal chemistry letters. 2016: 26(3): 809-13.

8. Oliveira AA, Oliveira APA, Franco LL, Ferencs MO, Ferreira JFG, Bachi SMPS, et al. 5-Nitroimidazolederived Schiff bases and their copper (II) complexes exhibit potent antimicrobial activity against pathogenic anaerobic bacteria. BioMetals. 2018: 31(4): 571-84.

9. Kumar SP, Suresh R, Giribabu K, Manigandan R, Munusamy S, Muthamizh S, et al. Synthesis and characterization of chromium (III) schiff base complexes: Antimicrobial activity and its electrocatalytic sensing ability of catechol. Spectrochimica Acta Part A: Molecular and Biomolecular Spectroscopy. 2015: 139: 431-41.

10. Kumar KS, Ganguly S, Veerasamy R, De Clercq E. Synthesis, antiviral activity and cytotoxicity evaluation of Schiff bases of some 2-phenyl quinazoline-4 (3) $\mathrm{H}$-ones. European journal of medicinal chemistry. 2010: 45(11): 5474-79.

11. Arora R, Gill NS, Kapoor A. Synthesis of Quinazolinone Based Schiff Bases as Potential Antiinflammatory and Analgesic Agents. Journal of Pharmacy and Allied Health Sciences. 2012: 4(1):15-23.

12. Arshad N, Ahmad M, Ashraf MZ, Nadeem H. Spectroscopic, electrochemical DNA binding and in vivo anti-inflammatory studies on newly synthesized Schiff bases of 4-aminophenazone. Journal of Photochemistry and Photobiology B: Biology. 2014: 138: 331-46.

13. Rakesh KP, Manukumar HM, Gowda DC. Schiff's bases of quinazolinone derivatives: Synthesis and SAR studies of a novel series of potential antiinflammatory and antioxidants. Bioorganic \& medicinal chemistry letters. 2015: 25(5): 1072-77.

14. Alafeefy AM, Bakht MA, Ganaie MA, Ansarie MN, El-Sayed NN, Awaad AS. Synthesis, analgesic, antiinflammatory and anti-ulcerogenic activities of certain novel Schiff bases as fenamate isosteres. Bioorganic \& medicinal chemistry letters. 2015: 25(2): 179-83.

15. Iftikhar B, Javed K, Khan, MS, Akhter Z, Mirza B, McKee V. Synthesis, characterization and biological assay of Salicylaldehyde Schiff base Cu (II) complexes and their precursors. Journal of Molecular Structure, 2018: 1155: 337-48.

16. Bhunora, S, Mugo J, Bhaw-Luximon A, Mapolie S, Van Wyk J, Darkwa J, Nordlander E. The use of Cu and $\mathrm{Zn}$ salicylaldimine complexes as catalyst precursors in ring opening polymerization of lactides: Ligand effects on polymer characteristics. Applied Organometallic Chemistry, 2011: 25(2): 133-45.

17. Kasumov VT. Synthesis, spectroscopic and redox properties of nickel(II) salicylaldimine complexes containing sterically hindered phenols. Transition Met. Chem. 2002: 27(2): 228-33.

18. Chen $W-H$, Wei H-H, Lee G-H, Wang Y. Dimeric iron (III) complexes with salicylaldimine ligands: structures, magnetic properties, and activity of $\mathrm{H}_{2} \mathrm{O}_{2}$ disproportionation. Polyhedron. 2001: 20(6): 515-21.

19. Andrezalova L, Plsikova J, Janockova J, Konarikova K, Zitnanova I, Kohutova M, KozurkovÂ M.

DNA/BSA binding ability and genotoxic effect of mono-and binuclear copper (II) complexes containing a Schiff base derived from salicylaldehyde and D, L-glutamic acid. Journal of Organometallic Chemistry. 2017: 827: 67-77.

20. Maurya MR, Gopinathan S, Gopinathan C, Maurya RC. Reactivity of bis (acetylacetonato) dinitrosylmolybdenum (0) towards schiff bases derived from salicylaldehyde or $o$-vanillin and benzoylhydrazide, or isonicotinoylhydrazide. Polyhedron, 1993: 12(2): 159-63.

21. Andruh $M$. The exceptionally rich coordination chemistry generated by Schiff-base ligands derived from o-vanillin. Dalton Transactions. 2015: 44(38): 16633-53.

22. Jayabalakrishnan C, Natarajan K. Ruthenium (II) carbonyl complexes with tridentate Schiff bases and their antibacterial activity. Transition Metal Chemistry, 2002: 27(1): 75-9.

23. Rodriguez MR, Del Pla J, Piro OE, Echeverria GA, Espino G, Pis-Diez R, et al. Structure, tautomerism, spectroscopic and DFT study of o-vanillin derived Schiff bases containing thiophene ring. Journal of Molecular Structure, 2018: 1165: 381-90.

24. Zdravkovski Z. Macedonian Journal of Chemistry and Chemical Engineering: Open Journal SystemsEditor's Perspective. Prilozi, 2015: 35(3): 51-5.

25. Abdel-Latif SA, Hassib HB, Issa YM. Studies on some salicylaldehyde Schiff base derivatives and their complexes with $\mathrm{Cr}$ (III), $\mathrm{Mn}$ (II), $\mathrm{Fe}(\mathrm{III}), \mathrm{Ni}(\mathrm{II})$ and $\mathrm{Cu}($ II). Spectrochim. Acta, Part A, 2007: 67A(3-4): 950-57.

26. Asiri AM, Badahdah KO. Synthesis of some new anils: Part 1. Reaction of 2-hydroxybenzaldehyde and 2-hydroxynaphthaldehyde with 2-aminopyridine and 2-aminopyrazine. Molecules, 2007: 12(8): 17961804.

27. Dhahagani K, Kumar SM, Chakkaravarthi G, Anitha K, Rajesh J, Ramu A et al. Synthesis and spectral characterization of Schiff base complexes of $\mathrm{Cu}$ (II), Co (II), Zn (II) and VO (IV) containing 4-(4aminophenyl) morpholine derivatives: Antimicrobial evaluation and anticancer studies. Spectrochimica Acta Part A: Molecular and Biomolecular Spectroscopy. 2014: 117: 87-94.

28. Sobola AO, Watkins GM. Spectroscopic Study of Keto-enol Tautomerism in $\mathrm{N}$-arylsalicylaldimine derivatives-Hydrogen Bonding and Electronic 
Effects of p-Substituents. FUW Trends in Science \& Technology Journal. 2018: 3(1): 92-5.

29. Percy GC, Thornton DA. N-Aryl salicylaldimine complexes. Infrared and PMR spectra of the ligands and vibrational frequencies of their metal(II) chelates. Journal of Inorganic and Nuclear Chemistry. 1972: 34: 3357-67.

30. Dollish, F.R., W.G. Fateley, and F.F. Bentley, Characteristic Raman Frequencies of Organic Compounds. New York: Wiley-Interscience; 1973.

31. Chatterjee KK, Douglas BE. The near ultraviolet spectra of some o-hydroxy aromatic Schiff bases. Comparison with the protonated and anionic forms. Spectrochimica Acta. 1965: 21(9): 1625-31.

32. Ledbetter JW Jr. Substituent effects on the tautomerism of Schiff bases. J. Phys. Chem., 1968. 72(12): p. 4111-15.
33. Saeed AAH, Mahmoud AAK, Saed HA. Electronic spectrophotometric study on the molecular structure of some hydroxy Schiff bases. Canadian Journal of Spectroscopy. 1988: 33(4): 89-93.

34. Wanger A, Disk diffusion test and gradient methodologies. In: Schwalbe R, Steele-Moore L, Goodwin A. editors: Antimicrobial testing protocols. Boca Raton: Taylor \& Francis Group; 2007.

35. Sobola AO, Watkins GM, Van Brecht B. Synthesis, characterization and antimicrobial activity of copper (II) complexes of some ortho-substituted aniline Schiff bases; crystal structure of bis (2-methoxy-6imino) methylphenol copper (II) complex. South African Journal of Chemistry, 2014: 67: 45 - 51. 